\title{
PEMODELAN MOLEKUL SENYAWA TURUNAN KOJIC ACID SERTA INTERAKSINYA DENGAN ENZIM TIROSINASE
}

\author{
Fazrul Permadi, Yusnita Rifai, Muhammad Aswad \\ Laboratorium Kimia, Fakultas Farmasi, Universitas Hasanuddin, Makassar
}

Kata Kunci :

kojic acid, kojyl

thioether, HKSA

Autodock Vina, Docking

\section{ABSTRAK}

Studi HKSA dilakukan pada turunan kojyl thioether sebagai inhibitor tirosinase. Perhitungan prediktor dilakukan menggunakan aplikasi hyperchem 8.0 dengan metode optimasi geometri semi-empirik PM3. Analisis regresi multilinear menggunakan SPSS 25.0 untuk mencari hubungan antara prediktor dan aktivitas senyawa turunan kojyl thioether sebagai inhibitor tirosinase. Model persamaan HKSA terbaik adalah :

$$
\mathrm{plC}_{50}=-92,517+15,872 * \mathrm{E}_{\text {LUMO }}-436,654 * \mathrm{qC} 4-209,509 * \mathrm{qC} 5+1,0008 \mathrm{e}^{-5 *} \mathrm{E}_{\text {in }}
$$$$
n=14 ; m=4 ; r=0,949 ; R^{2}=0,901 ; \text { PRESS }=3,0469 ; q^{2}=0,8246
$$

Berdasarkan persamaan HKSA diatas didapatkan 4 senyawa baru turunan kojyl thioether yang bisa dijadikan sebagai analog inhibitor tirosinase yang baru. Parameter pemilihan senyawa tersebut karena memiliki aktivitas yang lebih baik sebagai inhibitor tirosinase dibandingkan senyawa penuntun, tidak hepatotoksik, tidak menimbulkan AMES Toxicity, tidak menimbulkan skin sensititasion dan $L D_{50}$ pada tikus masuk kategori relatif tidak membahayakan. Untuk melihat interaksi antara senyawa turunun kojyl thioether dengan enzim tirosinase dilakukan docking menggunakan Autodock vina yang visualisasinya menggunakan discovery studio 2020 client. Hasil docking menunjukkan bahwa semua senyawa setidaknya memiliki interaksi pada residu asam amino yang penting yaitu his263 dan val283.

\begin{abstract}
Masuk 26-06-2020
Revisi 29-07-2020

Diterima 20-08-2020
\end{abstract}

DOI: $10.20956 / \mathrm{mff} . v 24 i 2.10517$

\section{Korespondensi}

Fazrul Permadi

Fazrulongkee@gmail.com

Copyright

C 2020 Majalah Farmasi

Farmakologi Fakultas Farmasi Makassar

Diterbitkan tanggal

20 Agustus 2020

Dapat Diakses Daring Pada: http://journal.unhas.ac.id/index.php/mff

\section{PENDAHULUAN}

Peningkatan aktivitas tirosinase menyebabkan kelainan pada warna kulit seseorang yang sering disebut dengan hiperpigmentasi [1]. Produk pencerah kulit digunakan agar masalah hiperpigmentasi kulit dapat diatasi. Senyawa yang terkandung dalam produk pencerah kulit biasanya memiliki aktivitas sebagai inhibitor tirosinase sehingga jumlah melananin dapat dikurangi. Hidroquinon merupakan senyawa inhibitor tirosinase yang baik tetapi memiliki efek samping yang berbahaya seperti iritasi dan bahkan kanker kulit [2,3]. Alternatif pengganti hidroquinon adalah kojic acid yang memiliki kelemahan berupa aktivitas yang kurang memadai sebagai inhibitor tirosinase. Hal ini mendasari banyak penelitian untuk mengoptimalkan aktivitas kojic acid sebagai inhibitor tirosinase sehingga dilakukan sintesis pada turunan kojic acid $[4,5]$. Salah satu hasil yang terbaik dilakukan oleh Rho et al. yang mensintesis 14 senyawa kojic acid bertipe kojyl thioether Didapatkan keseluruhan senyawa tersebut memiliki aktivitas yang lebih baik dibandingkan kocid acid itu sendiri sebagai inhibitor tirosinase berdasarkan uji in vitro [6].

Sejak ditemukannya mekanika kuantum, muncul cabang ilmu baru dalam bidang kimia yaitu kimia komputasi yang dapat meminimalkan proses trial and error sehingga biaya penelitian dapat ditekan serta waktu penelitian dapat dipersingkat. Kimia komputasi menggunakan hasil kimia teori yang diterjemehkan kedalam program komputer sehingga bisa menghitung sifat-sifat molekul beserta perubahnnya, yang mana sifat-sifat molekul obat sangat berhubungan dengan aktivitas obat. Kimia komputasi juga dapat melakukan simulasi terhadap sistem-sistem yang besar baik berupa gas, cairan, padatan ataupun kristal cair [7]. Pengetahuan tentang hubungan struktur kimia dan aktivitas biologisnya merupakan suatu dasar yang sangat penting dalam rancangan obat yang pertama kali dikemukakan oleh Crum, brown dab Fraser tahun 1869 [8].

Belum diketahui pengaruh sifat-sifat molekul dari turunan senyawa kojyl thioether terhadap aktivitas inhibitor tirosinasenya. Sehingga pada penelitian ini dilakukan suatu studi Hubungan Kuantitatif Struktur dan Aktivitas (HKSA) pada senyawa turunan kojyl thioeter untuk mencari adanya hubungan antara sifat-sifat dari molekul senyawa (prediktor) dengan aktivitasnya sebagai inhibitor tirosinase. Dengan adanya penelitian ini akan didapatkan sebuah persaman HKSA yang valid yang selanjutnya digunakan untuk mendesain senyawa baru yang berbasis pada kojyl thioeter. Semua senyawa modifikasi baru dapat diprediksi aktivitas inhibitor tirosinasenya berdasarkan persamaan HKSA yang didapatkan. Senyawa baru hasil modifikasi yang memiliki aktivitas prediksi yang lebih baik dibandingkan senyawa penuntun berdasarkan persamaan HKSA, akan dilanjutkan ketahap prediksi toksisitas [9]. Prediksi toksisitas perlu dilakukan mengingat suatu calon obat biasanya gagal diajukan sebagai obat karena bermasalah pada saat uji toksisitasnya. Senyawa desain dari model HKSA terpilih dan senyawa turunan kojyl thioeter yang digunakan untuk mendapatkan persamaan HKSA, dipelajari interaksinya dengan protein target (enzim tirosinase) melalui studi penambatan molekul (molecular docking). Penelitian ini adalah skrining awal untuk mendaptkan senyawa turunan kojyl thioeter baru yang kemungkinan memiliki aktivitas yang lebih baik lagi sebagai inhibitor tirosinase dengan meminimalisir proses trial and error. 


\section{METODE PENELITIAN}

Data struktur dan aktivitas 14 senyawa turunan kojyl thioeter sebagai inhibitor tirosinase diperoleh dari literatur [6] dapat dilihat pada gambar 1 dan tabel 1 . Aktivitas inhibisi dalam bentuk IC50 seluruh senyawa diubah menjadi pIC50.

\begin{tabular}{ccccc}
\multicolumn{5}{c}{ Tabel 1. Turunan senyawa kojyl thiother dan aktivitasnya } \\
\hline No. & Senyawa & $\begin{array}{c}\text { Rantai } \\
\text { samping }\end{array}$ & IC $50(\mu \mathrm{M})$ & pIC 50 \\
\hline 1. & $\mathrm{A} 1$ & $\mathrm{R}=-\mathrm{C}_{2} \mathrm{H}_{5}$ & 2,60 & -0.41497 \\
2. & $\mathrm{A} 2$ & $\mathrm{R}=-\mathrm{C}_{3} \mathrm{H}_{7}$ & 1,93 & -0.28555 \\
3 & $\mathrm{A} 3$ & $\mathrm{R}=-\mathrm{C}_{4} \mathrm{H}_{9}$ & 1,48 & -0.17026 \\
4. & $\mathrm{A} 4$ & $\mathrm{R}=-\mathrm{C}_{5} \mathrm{H}_{11}$ & 0,097 & 1.01322 \\
5. & $\mathrm{A} 5$ & $\mathrm{R}=-\mathrm{C}_{6} \mathrm{H}_{13}$ & 0,19 & 0.72124 \\
6. & $\mathrm{A} 6$ & $\mathrm{R}=-\mathrm{C}_{7} \mathrm{H}_{15}$ & 2,65 & -0.42324 \\
7. & $\mathrm{A} 7$ & $\mathrm{R}=-\mathrm{C}_{8} \mathrm{H}_{17}$ & 46,18 & -1.66445 \\
8. & $\mathrm{A} 8$ & $\mathrm{R}=-\mathrm{C}_{6} \mathrm{H}_{11}$ & 0,087 & 1.06048 \\
9. & $\mathrm{B} 1$ & $\mathrm{R}=-\mathrm{C}_{5} \mathrm{H}_{11}$ & 79,87 & -1.90238 \\
10. & $\mathrm{B} 2$ & $\mathrm{R}=-\mathrm{C}_{6} \mathrm{H}_{13}$ & 73,75 & -1.86776 \\
11. & $\mathrm{B} 3$ & $\mathrm{R}=-\mathrm{C}_{6} \mathrm{H}_{11}$ & 79,03 & -1.89779 \\
12. & $\mathrm{C} 1$ & $\mathrm{R}=-\mathrm{C}_{5} \mathrm{H}_{11}$ & 76,60 & -1.88422 \\
13. & $\mathrm{C} 2$ & $\mathrm{R}=-\mathrm{C}_{6} \mathrm{H}_{13}$ & 49,15 & -1.69152 \\
14. & $\mathrm{C} 3$ & $\mathrm{R}=-\mathrm{C}_{6} \mathrm{H}_{11}$ & 69,01 & -1.83891 \\
\hline
\end{tabular}<smiles>[R]SCc1cc(=O)c(O)co1</smiles>

Gambar 1. Struktur dasar kojyl thioether

\section{Optimasi senyawa dan perhitungan prediktor}

Seluruh 14 senyawa dilakukan optimasi geometri menggunakan perangkat lunak hyperchem 8.0 dengan metode semiempiris Parameterized Model 3 (PM3) menggunakan algoritma polak-ribiere, rms gradient 0,01 $\mathrm{kcal} / \mathrm{mol}$. Hasil perhitungan prediktor berupa Energi total (PM3_E), momen dipol (PM3_Dipol), Energi muatan bersih atom (PM3_q), panas pembentukan (PM3_HF), energi ikatan (PM3_Eik), Energi isolasi atom (PM3_Eis), Energi elektronik (PM3_Eele), dan interaksi inti (PM3_Eint) diperoleh dati file .log saat optimasi geometri, energy HOMO (PM3_HOMO) dan energy LUMO (PM3_LUMO) diperoleh pada menu orbitals sedangkan massa (BM), koefisien partisi $(\log \mathrm{P})$ dan volume van der waals (Vol) diperoleh lewat menu qsar property. Pemilihan prediktor sudah mewakili parameter elektronik, sterik dan hidrofobik.

\section{Membangun model HIKSA}

Analisis regresi multilinier dilakukan untuk mendapatkan persamaan HKSA dengan bantuan perangkat lunak SPSS 25 menggunakan metode stepwise, backward dan enter. Variabel bebas yang digunakan adalah descriptor senyawa sedangkan varibel terikatnya adalah aktivitas inhibitor tirosinase senyawa turunan kojic thioether yang dinyatakan dalam pIC50. Persamaan HKSA dipilih berdasarkan kriteria statistic seperti koefisien korelasi (r), koefisien determinasi (R2), nilai F dan standar error (SE). Selain itu, uji validasi silang leave one out (LOO) juga dilakukan untuk memastikan validitas persamaan terpilih dengan melihat nilai koefisien validasi silang (q2) terbesar $(\geq 0,5)$. LOO dilakukan dengan cara setiap senyawa pada data fitting dieliminasi kemudian dibangun persamaan HKSA yang baru dan aktivitas senyawa tersebut diprediksi menggunakan persamaan baru tanpa senyawa tersebut. Hal ini diulang untuk 14 senyawa [10].

Desain senyawa baru, uji toksisitas dan penambatan molekul

Berdasarkan persamaan HKSA terbaik dilakukan modifikasi struktur untuk mendaptkan senyawa turunan kojyl thioether baru yang mempunyai aktivitas inhibitor tirosinase yang lebih baik. Modifikasi dilakukan dengan mengganti siklohexil dengan benzene pada senyawa A8 (senyawa induk) untuk kemudian dimodifikasi lagi dengan menambahkan gugus $\mathrm{NO}_{2}, \mathrm{NH}_{2}, \mathrm{~F}$ atau $\mathrm{CH}_{3}$

Senyawa modifikasi yang memiliki aktivitas yang lebih baik dibanding senyawa A8 akan diuji toksisitasnya. Toksisitas prediksi yang diuji meliputi AMES toxicity, skin sensitization, hepatotoksik dan $\mathrm{LD}_{50}$ pada tikus. Pengujian dilakukan secara online menggunakan pkcsm [11].

Molecular docking dilakukann menggunakan perangkat lunak Autodock vina pada enzim tirosinase dengan kode pdb $2 \mathrm{y} 9 \mathrm{x}$ [12]. Pengaturan posisi grid box yaitu $X=-2,373, Y=26,369$ dan $\mathrm{Z}=-41,337$ dengan ukuran $\mathrm{X}=18, \mathrm{Y}=20$ dan $\mathrm{Z}=16$. Visualisasi hasil penambatan menggunakan perangkat lunak discovery studio 2020 client.

\section{HASIL DAN PEMBAHASAN}

HKSA dimlai dengan melakukan optimasi geometri ke empat belas data fitting menggunakan perangkat lunak Hyperchem 8,0 agar didapatkan prediktor dari senyawa-senyawa tersebut. Analisis regresi multilinier dilakukan dengan menggunakan perangkat lunak SPSS 25 dengan pIC 50 sebagai variable terikat dan prediktor sebagai variable bebasnya. Persamaan HKSA yang didapatkan kemudian dirangking berdasarkan parameter statisticnya seperti $r, \mathrm{R}^{2}$, nilai $\mathrm{F}$ dan SE. Dilakukan uji validitas pada persamaan menggunakan validasi silang leave one out (LOO) untuk melihat nilai $\mathrm{q}^{2}$ yang harus $\geq 0,6$ [10]. Didapatkan persamaan HKSA terbaik yang valid dengan parameter $: \mathrm{n}=14 ; \mathrm{m}=4 ; \mathrm{r}=0,946 ; \mathrm{R}^{2}=0,901$; $\mathrm{F}_{\text {hit }} / \mathrm{F}_{\mathrm{tab}}=5,6 ; \mathrm{SE}=0,436$ dan $\mathrm{q}^{2}=0,8246$

$\mathrm{pIC}_{50}=-92,517+15,872 *$ Elumo $-436,654 * \mathrm{qC} 4-209,509 * \mathrm{qC} 5$ $+1,0008 \mathrm{e}^{-5 *} \mathrm{E}_{\text {in }}$

Berdasarkan model HKSA diatas, parameter elektronik merupakan satu-satunya parameter yang berpengaruh terhadap aktivitas inhibitor tirosinase senyawa turunan kojyl thioether. Hal ini sesuai dengan pernyataan siswandono yang menyatakan bahwa ikatan antara senyawa-reseptor dipengaruh terutama oleh parameter elektronik dengan sedikit pengaruh parameter sterik. Nilai $\mathrm{R}^{2}$ sebesar 0,901 menandakan bahwa 90,1\% aktivitas inhibitor tirosinase dipengaruhi oleh ke empat prediktor, sisanya bisa jadi dipengaruhi oleh parameter sterik dan lain hal yang tidak dapat dijelaskan berdasarkan persamaan HKSA [8]. Semakin besar $\mathrm{E}_{\mathrm{LUM}}$ dan $\mathrm{E}_{\text {int }}$ akan meningkatkan aktivitas inhibitor tirosinase. Sebaliknya, semakin kecil nilai qC4 dan qC5 akan meningkatkan aktivitas inhibitor tirosinasenya.

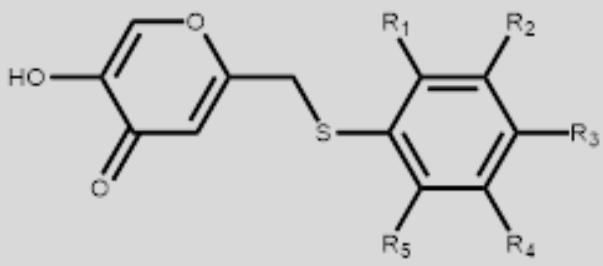

Gambar 2. Struktur dasar senyawa modifikasi

Dari data fitting, senyawa yang memiliki aktivitas terbaik adalah senyawa A8 yang memiliki rantai samping berupa siklohexil. Modifikasi struktur model pendekatan Topliss 
hanya dikelompokkan menjadi dua yaitu modifikasi cincin pada struktur aromatic dan modifikasi struktur pada rantai samping gugus alkil (alifatik), tidak ada modifikasi struktur pada struktur siklik [8]. Dengan alasan itu, cincin siklohexil diganti dengan cincin aromatic berupa benzene yang kemudian dilakukan modifikasi lagi dengan penambahan $\mathrm{NO}_{2}, \mathrm{NH}_{2}, \mathrm{~F}$ atau $\mathrm{CH}_{3}$. Didapatkan lima belas senyawa yang memiliki aktivitas inhibitor tirosinase yang lebih baik dibanding senyawa A8.
Dari ke lima belas senyawa baru hasil modifikasi struktur hanya didapatkan empat senyawa yang memiliki toksisitas yang baik yaitu KT $1 \mathrm{Me}$, KT 1,2,5 NH2, KT 1,3 NH2 dan KT 1,5 F. Senyawa terbaik hasil modifikasi adalah KT 1,3 NH2 dengan pIC $_{50}$ prediksi sebesar 9,77439, dan $\mathrm{LD}_{50}$ pada tikus sebesar 731.863,3 mg/kg yang termasuk dalam kategori 6 atau relatif tidak membahayakan. Nilai pIC 50 prediksi dan toksisitas prediksi dari senyawa baru hasil modifikasi dapat dilihat pada Tabel 2 .

\begin{tabular}{|c|c|c|c|c|c|c|c|}
\hline No. & Senyawa & struktur & $\begin{array}{c}\text { pIC }_{50} \text { prediksi } \\
(\mu \mathrm{M})\end{array}$ & $\begin{array}{c}\text { AMES } \\
\text { toxicity }\end{array}$ & Hepatotoksik & $\begin{array}{c}\text { Skin } \\
\text { sensitisation }\end{array}$ & $\begin{array}{c}\text { LD }_{50} \text { tikus } \\
\text { (mg/Kg) }\end{array}$ \\
\hline 1. & KT $1 \mathrm{~F}$ & $\begin{array}{c}\mathrm{R}_{1}=\mathrm{F} \\
\mathrm{R}_{2}=\mathrm{R}_{3}=\mathrm{R}_{4}=\mathrm{R}_{5}=\mathrm{H}\end{array}$ & 4,18935 & Yes & Yes & No & $555.489,7$ \\
\hline 2. & KT $1 \mathrm{Me}$ & $\begin{array}{c}\mathrm{R}_{1}=\mathrm{CH}_{3} \\
\mathrm{R}_{2}=\mathrm{R}_{3}=\mathrm{R}_{4}=\mathrm{R}_{5}=\mathrm{H}\end{array}$ & 6,13555 & No & No & No & $585.250,1$ \\
\hline 3. & $\mathrm{KT} 1 \mathrm{NH} 2$ & $\begin{array}{c}\mathrm{R}_{1}=\mathrm{NH}_{2} \\
\mathrm{R}_{2}=\mathrm{R}_{3}=\mathrm{R}_{4}=\mathrm{R}_{5}=\mathrm{H}\end{array}$ & 7,92497 & Yes & No & No & $682.209,4$ \\
\hline 4. & KT 1,2 NH2 & $\begin{array}{c}\mathrm{R}_{1}=\mathrm{R}_{2}=\mathrm{NH}_{2} \\
\mathrm{R}_{3}=\mathrm{R}_{4}=\mathrm{R}_{5}=\mathrm{H}\end{array}$ & 7,95463 & Yes & No & No & $765.694,4$ \\
\hline 5. & KT $1,2,3 \mathrm{NH} 2$ & $\begin{array}{c}\mathrm{R}_{1}=\mathrm{R}_{2}=\mathrm{R}_{3}=\mathrm{NH}_{2} \\
\mathrm{R}_{4}=\mathrm{R}_{5}=\mathrm{H}\end{array}$ & 9,23232 & No & Yes & No & $756.959,9$ \\
\hline 6. & KT $1,2,4 \mathrm{NH} 2$ & $\begin{array}{c}\mathrm{R}_{1}=\mathrm{R}_{2}=\mathrm{R}_{4}=\mathrm{NH}_{2} \\
\mathrm{R}_{3}=\mathrm{R}_{5}=\mathrm{H}\end{array}$ & 7,96883 & Yes & No & No & $787.126,5$ \\
\hline 7. & KT $1,2,5 \mathrm{NH} 2$ & $\begin{array}{c}\mathrm{R}_{1}=\mathrm{R}_{2}=\mathrm{R}_{5}=\mathrm{NH}_{2} \\
\mathrm{R}_{3}=\mathrm{R}_{4}=\mathrm{H}\end{array}$ & 4,01326 & No & No & No & $778.188,3$ \\
\hline 8. & KT 1,3 NH2 & $\begin{array}{c}\mathrm{R}_{1}=\mathrm{R}_{3}=\mathrm{NH}_{2} \\
\mathrm{R}_{2}=\mathrm{R}_{4}=\mathrm{R}_{5}=\mathrm{H}\end{array}$ & 9,77439 & No & No & No & $731.863,3$ \\
\hline 9. & KT 1,3,4 NH2 & $\begin{array}{c}\mathrm{R}_{1}=\mathrm{R}_{3}=\mathrm{R}_{4}=\mathrm{NH}_{2} \\
\mathrm{R}_{2}=\mathrm{R}_{5}=\mathrm{H}\end{array}$ & 8,96785 & No & Yes & No & $729.307,1$ \\
\hline 10. & KT $1,3,5 \mathrm{NH} 2$ & $\begin{array}{c}\mathrm{R}_{1}=\mathrm{R}_{3}=\mathrm{R}_{5}=\mathrm{NH}_{2} \\
\mathrm{R}_{2}=\mathrm{R}_{4}=\mathrm{H}\end{array}$ & 6,32150 & No & Yes & No & $737.686,7$ \\
\hline 11. & KT 1,4 NH2 & $\begin{array}{c}\mathrm{R}_{1}=\mathrm{R}_{4}=\mathrm{NH}_{2} \\
\mathrm{R}_{2}=\mathrm{R}_{3}=\mathrm{R}_{5}=\mathrm{H}\end{array}$ & 7,71662 & Yes & No & No & 754.065 \\
\hline 12. & KT $1,5 \mathrm{~F}$ & $\begin{array}{c}R_{2}=R_{5}=F \\
R_{1}=R_{3}=R_{4}=H\end{array}$ & 2,12363 & No & No & No & $620.237,5$ \\
\hline 13. & KT 1,5 NH2 & $\begin{array}{c}\mathrm{R}_{2}=\mathrm{R}_{5}=\mathrm{NH}_{2} \\
\mathrm{R}_{1}=\mathrm{R}_{3}=\mathrm{R}_{4}=\mathrm{H}\end{array}$ & 4,19088 & No & Yes & No & $441.655,3$ \\
\hline 14. & KT 2,3,4 NH2 & $\begin{array}{c}\mathrm{R}_{2}=\mathrm{R}_{3}=\mathrm{R}_{4}=\mathrm{NH}_{2} \\
\mathrm{R}_{1}=\mathrm{R}_{5}=\mathrm{H}\end{array}$ & 7,13280 & Yes & No & No & 799.696 \\
\hline 15. & KT $3 \mathrm{NH} 2$ & $\begin{array}{c}\mathrm{R}_{3}=\mathrm{NH}_{2} \\
\mathrm{R}_{1}=\mathrm{R}_{2}=\mathrm{R}_{4}=\mathrm{R}_{5}=\mathrm{H}\end{array}$ & 6,95131 & Yes & No & No & $662.366,1$ \\
\hline
\end{tabular}



Gambar 3. Visualisasi Validasi Metode (biru = native ligan, merah = ligan redocking)

Penambatan molekul dilakukan menggunakan perangkat lunak autodock vina pada enzim tirosinase dengan kode pdb 2y9x untuk melihat interaksi antara enzim dengan senyawa. Pemilihan enzim tirosinase $2 \mathrm{y} 9 \mathrm{x}$ adalah karena enzim ini berasal dari spesies Agaricus bisporus yang mana enzim tirosinase dari spesies ini diperjul belikan secara komersial dan similaritasnya paling mirip dengan enzim tirosinase pada manusia [13]. Sebelum dilakukan penambatan molekul pada senyawa, terlebih dahulu harus dilakukan validasi metode dengan cara meredocking native ligan 2y9x (tropolone). Didapatkan hasil yang valid dengan nilai RMSD 1,26356 Á (< 2 Á) yang diukur dan divisualisasikan menggunakan discovery studio 2020 client yang terlihat pada gambar 3 . Tropolone memiliki afinitas sebesar $-6,2 \mathrm{kcal} / \mathrm{mol}$ dan berinteraksi dengan residu asam amino berupa ikatan karbon dengan His61, ikatan karbon dengan his259, ikatan pi-donor dan pi-pi stacked dengan his263, ikatan pi-sigma dengan val283 dan ikatan pi-alkil dengan ala286. Senyawa A8 yang merupakan senyawa terbaik pada data fitting memiliki afinitas yang lebih baik dibandingkan tropolone yaitu $-6,5$ $\mathrm{kcal} /$ mol dengan interaksi pada residu asam amino berupa ikatan karbon dengan his61, ikatan pi-alkil dengan his244, ikatan pi-donor dan pi-alkil dengan his263, ikatan konvensional dengan met280, ikatan alkil dengan val283, ikatan alkil dengan ala286. Untuk senyawa terbaik hasil modifikasi yaitu KT 1,3 NH2 memiliki afinitas $-6,7 \mathrm{kcal} / \mathrm{mol}$ dengan interaksi pada residu asam amino berupa ikatan pi-alkil dengan his61, ikatan konvensional dan ikatan pi-alkil dengan his85, ikatan konvensional dan ikatan pi-alkil dengan his244, ikatan pialkil dengan his259, ikatan pi-alkil dengan his263, ikatan konvensional dengan met280, ikatan alkil dengan val283, ikatan alkil dengan ala286. Enzim tirosinase merupakan suatu metaloprotein yang memiliki 2 ion tembaga $\left(\mathrm{Cu}^{2+}\right)$ yang setiap ionnya berikatan koordinasi dengan 3 residu histidine. $\mathrm{Cu}-\mathrm{A}$ berikatan dengan residu histidin61, 85, 94 dan $\mathrm{Cu}-\mathrm{B}$ berikatan dengan residu histidin259, 263, 296. Posisi ikatan 
Tabel 3. Hasil docking dan interaksi dengan residu asam amino seluruh senyawa

\begin{tabular}{|c|c|c|c|}
\hline No. & Senyawa & $\begin{array}{c}\text { Afinitas } \\
\text { (kcal/mol) }\end{array}$ & $\begin{array}{c}\text { Interakasi residu asam } \\
\text { amino }\end{array}$ \\
\hline 1 & native ligan & $-6,2$ & $\begin{array}{l}\text { His61, His259, His263, } \\
\text { Val283,Ala286 }\end{array}$ \\
\hline 2 & $\mathrm{~A} 1$ & $-5,4$ & $\begin{array}{l}\text { His61, His263, Met280, Val283, } \\
\text { Ala286 }\end{array}$ \\
\hline 3 & $\mathrm{~A} 2$ & $-5,4$ & $\begin{array}{c}\text { His61, His263, Met280, Val283, } \\
\text { Ala286 }\end{array}$ \\
\hline 4 & A3 & $-5,4$ & $\begin{array}{c}\text { His61, His263, Met280, Val283, } \\
\text { Ala286 }\end{array}$ \\
\hline 5 & A4 & $-5,3$ & $\begin{array}{l}\text { His259, His263, Phe264, } \\
\text { Met280, Val283,Ala286 }\end{array}$ \\
\hline 6 & A5 & $-5,6$ & $\begin{array}{c}\text { His61, His263, Met280, Val283, } \\
\text { Ala286 }\end{array}$ \\
\hline 7 & A6 & $-5,7$ & $\begin{array}{c}\text { His61, His263, Met280, Val283, } \\
\text { Ala286 }\end{array}$ \\
\hline 8 & A7 & $-5,6$ & Asn81, His85, Val283 \\
\hline 9 & A8 & -6.5 & $\begin{array}{c}\text { His61, His244, His263, Met280, } \\
\text { Val283, Ala286 }\end{array}$ \\
\hline 10 & B1 & -5.7 & $\begin{array}{c}\text { His61, His263, Met280, Val283, } \\
\text { Ala286 }\end{array}$ \\
\hline 11 & B2 & $-5,8$ & $\begin{array}{c}\text { Asn81, His85, His244, Asn260, } \\
\text { His263, Val283 }\end{array}$ \\
\hline 12 & B3 & $-6,6$ & $\begin{array}{c}\text { His244, Val,248, His259, His263, } \\
\text { Phe264, Met280, Val283, } \\
\text { Ala286 }\end{array}$ \\
\hline 13 & $\mathrm{C} 1$ & $-6,0$ & $\begin{array}{c}\text { His85, His244, Glu256, Asn260, } \\
\text { Val283 }\end{array}$ \\
\hline 14 & $\mathrm{C} 2$ & $-6,2$ & $\begin{array}{c}\text { His85, His244, Asn260, His263, } \\
\text { Val283 }\end{array}$ \\
\hline 15 & C3 & $-6,6$ & $\begin{array}{l}\text { His244, Val246, His259, His263, } \\
\text { Phe264, Met280, Val283 }\end{array}$ \\
\hline 16 & KT $1 \mathrm{~F}$ & $-6,9$ & $\begin{array}{l}\text { His244, His263, Met280, } \\
\text { Ser282, Val283, Ala286 }\end{array}$ \\
\hline 17 & KT $1 \mathrm{Me}$ & $-6,6$ & His244, His263, Val283 \\
\hline 18 & $\mathrm{KT} 1 \mathrm{NH} 2$ & $-6,8$ & $\begin{array}{l}\text { His244, His263, Phe264, } \\
\text { Met280, Val283, Ala286 }\end{array}$ \\
\hline 19 & KT 1,2 NH2 & $-6,6$ & $\begin{array}{l}\text { Asn81, His85, His244, Phe264, } \\
\text { Val283 }\end{array}$ \\
\hline 20 & $\begin{array}{c}\text { KT } 1,2,3 \\
\mathrm{NH} 2\end{array}$ & $-6,4$ & $\begin{array}{l}\text { His61, His85, His244, His259, } \\
\text { Asn260, His263, Val283, Ala286 }\end{array}$ \\
\hline 21 & $\begin{array}{c}\text { KT } 1,2,4 \\
\text { NH2 }\end{array}$ & $-7,1$ & $\begin{array}{l}\text { His85, His244, His259, His263, } \\
\text { Phe264, Val283 }\end{array}$ \\
\hline 22 & $\begin{array}{c}\text { KT } 1,2,5 \\
\text { NH2 }\end{array}$ & $-6,4$ & $\begin{array}{l}\text { His61, His85, His244, His259, } \\
\text { Asn260, His263, Val283, Ala286 }\end{array}$ \\
\hline 23 & KT 1,3 NH2 & $-6,7$ & $\begin{array}{l}\text { His61, His85, His244, His259, } \\
\text { His263, Met280, Val283, Ala286 }\end{array}$ \\
\hline 24 & $\begin{array}{c}\text { KT } 1,3,4 \\
\mathrm{NH} 2\end{array}$ & $-6,7$ & $\begin{array}{l}\text { His61, His85, His244, His259, } \\
\text { His263, Met280, Val283 }\end{array}$ \\
\hline 25 & $\begin{array}{c}\text { KT } 1,3,5 \\
\mathrm{NH} 2\end{array}$ & $-6,3$ & $\begin{array}{l}\text { His61, His85, His244, His259, } \\
\text { Asn260, His260, Val283, Ala286 }\end{array}$ \\
\hline 26 & KT 1,4 NH2 & $-6,9$ & $\begin{array}{l}\text { His61, His85, His244, His259, } \\
\text { His263, Met280, Val283 }\end{array}$ \\
\hline 27 & KT 1,5 F & $-6,9$ & $\begin{array}{l}\text { His244, His259, Asn260, His263, } \\
\text { Met280, Gly281,Val283 }\end{array}$ \\
\hline 28 & KT 1,5 NH2 & $-6,5$ & $\begin{array}{c}\text { His85, His259, Asn260, His263, } \\
\text { Phe264, Met280, Gly281, } \\
\text { Val283 }\end{array}$ \\
\hline 29 & $\begin{array}{c}\text { KT 2,3,4 } \\
\text { NH2 }\end{array}$ & $-6,4$ & $\begin{array}{l}\text { His61, His85, His244, His259, } \\
\text { His263, Val283 }\end{array}$ \\
\hline 30 & KT $3 \mathrm{NH} 2$ & $-6,5$ & $\begin{array}{l}\text { His61, His263, Phe264, Arg268, } \\
\text { Met280, Val283, Ala286 }\end{array}$ \\
\hline
\end{tabular}

tropolone di binding site ion tembaga $\left(\mathrm{Cu}^{2+}\right)$ enzim tirosinase $2 \mathrm{y} 9 \mathrm{x}$ mirip dengan posisi tirosin(substrat) pada enzim tirosinase dari spesies Streptomyces castaneoglobisporus [12]. Dapat diartikan bahwa tropolone ataupun senyawa-senyawa yang memiliki interaksi pada binding site ion tembaga $\left(\mathrm{Cu}^{2+}\right)$ memiliki aktivitas sebagai inhibitor kompetitif karena menempati posisi yang sama dengan tirosin(substrat). Pada binding site, terdapat 2 residu asam amino yang masuk dalam jarak ikatan van der walls dengan tropolone yaitu val283 dan his263. Rantai samping dari residu asam amino phe264 memiliki interaksi aromatik dengan tropolone. Residu asam amino lain yang ada pada binding site adalah his244, glu256, asn260, residu asam amino nomor 279-282 dan ala286. His263 juga berdasarkan hipotesis memegang peranan penting dari aktivitas monofenolase terhadap substrat(tirosin) melalui ikatan hidrofobik antara substrat dan $\mathrm{Cu}-\mathrm{B}$ yang berkoordinasi dengan his263 [12]. Visualisasi dari ketiga senyawa ini dapat dilihat pada gambar 4, 5 dan 6 sedangkan untuk nilai afinitas dan interaksi seluruh senyawa dengan residu asam amino dapat dilihat pada Tabel 3.

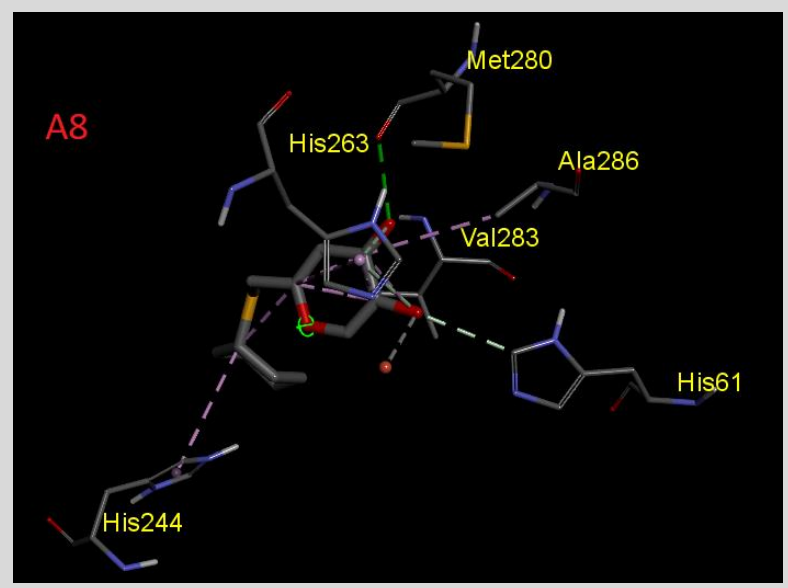

Gambar 4. Visualisasi interaksi senyawa A8 dengan residu asam amino

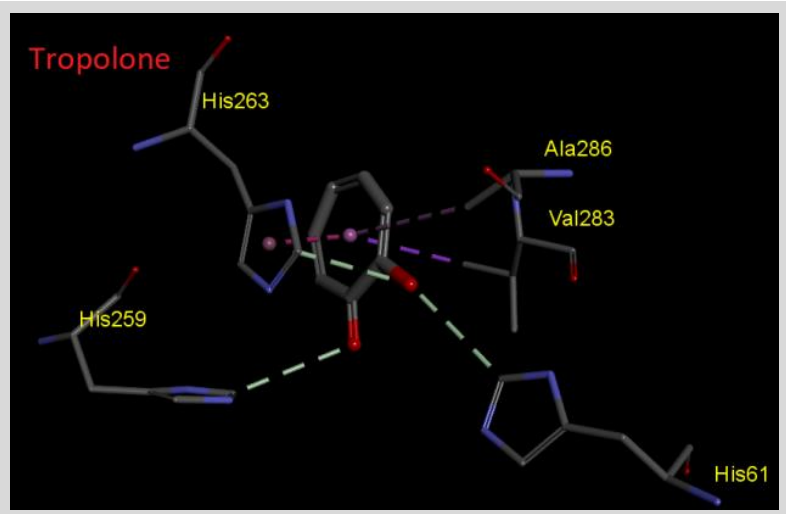

Gambar 5. Visualisasi interaksi senyawa Tropolone dengan residu asam amino

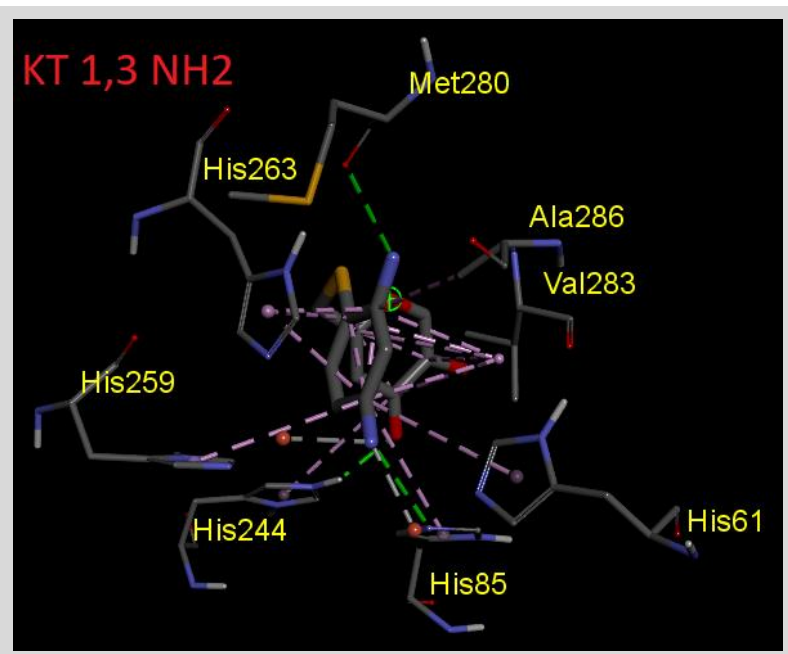

Gambar 6. Visualisasi interaksi senyawa KT 1,3 NH2 dengan residu asam amino

\section{KESIMPULAN}

Pada penelitian ini telah dibangun model persamaan HKSA yang valid yang bisa menghubungkan antara aktivitas senyawa sebagai inhibitor tirosinase dan struktur kimia senyawa kojyl thioether. Desain senyawa baru menggunakan persamaan HKSA didapatkan empat senyawa yang berpotensi sebagai analog inhibitor tirosinase yang baru. Seluruh senyawa sedikitnya memiliki satu interaksi pada residu asam amino penting yaitu pada residu asam amino His263 dan Val283.

\section{DAFTAR PUSTAKA}

1. Fistarol S. K., Itin P.H. 2010. Disorders of pigmentation. Journal of the German Society of dermatology. Vol. 8, 187-202. 
2. Gillbro J. M., Olsson M. J. 2011. The Melanogenesis and mechanisms of skin-lightening agents-existing and new approaches. Int J Cosmet Sci. Vol. 33, 210-221

3. Arbab, A. H. H., Eltahir M. M. 2010. Review on skin Whitening Agents Khartoun Pharmacy Journal. Vol. 13, 5-9.

4. Kim H., Jaehui C., Jin K. C., Sun Y K. Yoon-Sik L. 2004. Solid-Phase Synthesis of Kojic Acid-tripeptides and their Tyrosinase Inhibitory Activity, Storage Stability, and Toxicity. Bioorganic and Medical Chemistry Letters. Vol 14, 2843-2846.

5. Rho H. S., Heung S. B., Soo M. A., Duck H. K., Ih S. C. 2008. Synthesis Of new Anti-melanogenic Compounds Containing Two Molecules of kojic Acid. Bull Korean Chem Soc. Vol. 29(8), 1569-1571.

6. Rho H. S., Soo M. A., Dae S. Y., Myung K. K., Dong H. C. Jae Y. C. 2010. Kojyl thiother derivates having both tyrosinase inhibitory and antoinflamatory properties. Bioorganic and Medical Chemistry Letters. Vol. 10 6569-6571.

7. Prianto B. 2010. Pemodelan kimia Komputasi. Bidang Material Dirgantara.
8. Siswandono, Soekardjo, B. 2016. Kimia Medisinal 1, Jilid 2. Airlangga University Press, Surabaya.

9. Pires D. E. V., Blundell T. L., Ascher D. B. 2015. pkCSM: Predicting SmallMolecule Pharmacokinetic and Toxicity Properties Using Graph-Based Signatures, Medicinal Chemistry, Vol. 58, 4066-4072.

10. Golbraikh A., Shen M., Xiao Z., Xiao Y.D., Lee K.H., Tropsha A. 2003. Rational selection of training and test sets for the development of validated QSAR models. Journal of Computer-Aided Molecular Design. 17 : 241-253.

11. http://biosig.unimelb.edu.au/pkcsm/admet_prediction

12. Ismaya W.T., Rozeboom H.J., Weijn A., Mes J. J., Fusetti F., Wichers H.J., et al. 2011. Crystal structure of Agaricus bisporus mushroom tyrosinase: identity of the tetramer subunits and interaction with tropolone. Biochemistry. Vol. 50(24), 5477-5486.

13. Jung H. J., Noh S. G., Park Y., Kang D., Chun P., Chung H. Y., Moon H. R. 2019. In vitro and in silico insights into tyrosinase inhibitors with (E)benzylidene-1-indanone derivatives. Computational and Structural Biotechnology Journal. 